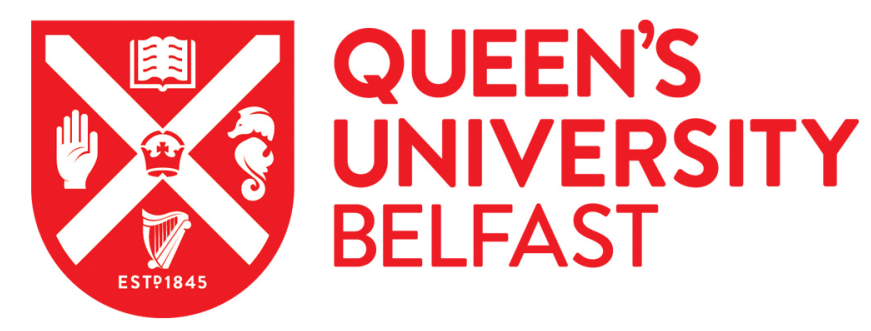

\title{
Students' reception of peer assessment of group-work contributions: problematics in terms of race and gender emerging from a South African case study
}

Thondhlana, G., \& Belluigi, D. Z. (2017). Students' reception of peer assessment of group-work contributions: problematics in terms of race and gender emerging from a South African case study. Assessment in Higher Education, 42(7), 1118-1131. https://doi.org/10.1080/02602938.2016.1235133

\section{Published in:}

Assessment in Higher Education

\section{Document Version:}

Peer reviewed version

Queen's University Belfast - Research Portal:

Link to publication record in Queen's University Belfast Research Portal

\author{
Publisher rights \\ (c) 2016 Informa UK Limited, trading as Taylor \& Francis Group. This work is made available online in accordance with the publisher's \\ policies. Please refer to any applicable terms of use of the publisher.
}

\section{General rights}

Copyright for the publications made accessible via the Queen's University Belfast Research Portal is retained by the author(s) and / or other copyright owners and it is a condition of accessing these publications that users recognise and abide by the legal requirements associated with these rights.

Take down policy

The Research Portal is Queen's institutional repository that provides access to Queen's research output. Every effort has been made to ensure that content in the Research Portal does not infringe any person's rights, or applicable UK laws. If you discover content in the Research Portal that you believe breaches copyright or violates any law, please contact openaccess@qub.ac.uk. 


\section{Students' reception of peer assessment of group-work contributions: Problematics in terms of race and gender emerging from a South African case study}

Gladman Thondhlana ${ }^{1}$ and Dina Zoe Belluigi ${ }^{2}$

1Department of Environmental Science, Rhodes University, South Africa.

2Centre for Higher Education Research, Teaching and Learning, Rhodes University, P. O. Box 94, Grahamstown, 6140, South Africa.

d.belluigi@ru.ac.za (Corresponding author) 


\section{Abstract}

Participatory assessment is increasingly employed in higher education worldwide as a formative mechanism to support students' active learning. But do students in an increasingly relationally diverse environment perceive that peer assessment of individuals' contribution to group-work tasks enhances their learning? Recognising the impact of students' conceptions on the quality of their learning, this study considers students' perspectives of peer assessment of group-work contributions at a South African university. Questionnaires elicited students' perspectives of and general attitudes towards assessment of and by their peers. A growing measure of discontent with the process of assessing peer contributions to group tasks emerged, including actual and perceived racial and gender stereotyping, and related rejection-sensitivity. These initial findings were checked against the students' experiences in a report-and-respond process that enabled probing discussions of the interpretations. This paper examines and explores the implications of such identifications and receptions for learning engagement and group-work curriculum development in the context of a rapidly transforming higher education sector.

\section{Introduction}

Contemporary notions of learning acknowledge the importance of students' active participation as critical actors in the learning process. Informed by research on the value of active learning and the social construction of knowledge, through the dynamic interplay between complex situational factors and identification (Shepard 2008), student involvement in what is known as 'participatory assessment' has been increasingly championed and practiced as an integral component of many formative assessment tasks (Boud \& Falchikov 2006; Gielen et al. 2011). Students' ability to make informed judgements and exercise discernment, developed through assessment, is seen as critical to learning in academia and in preparation for the working world (Boud 2000; Yorke 2001; Boud \& Falchikov 2006). In addition to tasks aimed at self-assessment directly, peer assessment utilises external assessment to provide a model for students' internal self-assessment of their own learning process and performance, thereby developing their metacognition. PA extends from assessment of the product of their learning (the quality of student performance or demonstrated outcomes in their work); to that of fellow group members' contributions in the process towards that outcome. This paper focusses on this latter aspect: the peer assessment of group-members' contributions.

Five overarching and often interrelated purposes of the peer assessment of group-members' contributions can be distinguished, namely as a tool for social control; for active participation of students; for learning; for assessment; and for learning-how-to-assess (Yorke 2001). Participants are often most concerned with reliability (consistency in marks across time, markers and methods) and validity (that the mode and method of assessment both develop and measure the achievement of desired learning outcomes) (Knight 2001; Bloxham \& Boyd 2007). Many scholars argue that grading systems are fraught with problems (such as Johnston \& Miles 2004), including mismatches between students' and teachers' grading, and students' self-bias when rating their own group contribution more highly than that of fellow group members. Others have found that there is high 
validity and inter-rater reliability within peer assessment, even in alternative contexts such as online environments (De Wever et al. 2011) and norm-referenced approaches (Jones \& Alcock 2014). As feedback influences learning (Hattie 1987), the peer assessment of group-members' contributions based on allocation of marks alone, without detailed feedback by the students' peer, may not adequately scaffold learning or develop critical judgement. Assessment practicability, in terms of the time needed to complete marking a given task; and transparency, where information, guidance and rules on assessment are clear, relevant, consistent and accessible to staff and students, are highlighted in assessment literature (Bloxham \& Boyd 2007).

The effectiveness of peer assessment in promoting student learning is conditioned by several factors. When it comes to assessing their peers' contributions to group tasks, students navigate complex trajectories as they both collaborate and fight for marks (Orr 2010). As assessment is a socially situated practice both informed by and mediated through the socio-political context within which it occurs, dynamics within small groups act as a social microcosm of the wider society in which they are located (Brown \& Mistry 1994). Plagued by similar equity issues as those found in wider society, social biases and partiality may influence judgement in peer assessment. Thus, whilst there has been substantial research on methods for assessing group-members' contributions (Lejk et al. 1996; Freeman \& McKenzie 2002), this paper is concerned with insights into student experiences and perceptions of the peer assessment of group-members' contributions in a particular context. This is both because the effectiveness with which academic tasks can be performed with is contingent upon the extent to which individual members are alienated or engaged in group-based activities (Chemers et al. 2001). Thus, we believe issues of potential social exclusion based on various indications of difference should be carefully considered and understood when thinking about the praxis and practice of peer assessment.

Some studies have suggested a mis-fit between the discourses of teamwork and communitybuilding associated with group-work, and the characteristics of students' interactions and experiences in groups (Crossouard 2012). As an individual interacts in a group, s/he selfcategorises him/herself by who is the same or other in relation to the self (Turner et al. 1987) and thereby defines him/herself either by personal attributes or group membership - personal or social identity. How the individual identifies with the normative content of the group, impacts on his/her self-definitions in terms of group membership, and the contrasts s/he creates with those outside the group, a process which engenders self-stereotyping (Hogg \& Turner 1987) when comparing with those who are similar (ingroup members) and those treated as different or 'other' (outgroup). This introduces problematics such as stereotype vulnerability, which is "the tendency to expect, perceive, and be influenced by negative stereotypes about one's social category" (Aronson \& Inzlicht 2004, 829). Such 'rejection sensitivity' (RS) is the tendency to perceive social-identity threats. In cases where stigmatization occurs, this may result in 'belonging uncertainty', with individuals becoming highly sensitive about how the quality of their social connections are assessed (Walton \& Cohen 2007). As the context of the peer assessment of group-members' 
contributions involves the evaluation of one's performance as a group member, such concerns are key.

While students generally have been shown to have a high degree of satisfaction with the process of the peer assessment of group-members' contributions (Brooks \& Ammons 2003; Maiden \& Perry 2011), the nuances of particular contexts and periods in time require one to question blanket assumptions about such findings being transferable. Increasing participation of students from diverse backgrounds requires reconsideration of how assessment might be adapted to the needs of various students while maintaining quality learning. In South African higher education institutions, as is the case internationally, the student body is becoming more diverse - consistent with national and institutional polices on widening participation and transformation in the higher education sector (Cross \& Carpentier 2009). With an increasingly diverse body of students, in terms of race, ethnicity, gender, socio-economic, linguistic and academic backgrounds, the implementation of peer assessment may become more complex. Particularly if one thinks of the nature of how stereotypes develop, and how in the absence of interaction and in historical contexts of behavioural discrimination, those stereotypes may be used to justify prejudice (Crandall et al. 2011).

Recognising that the content of social identity and group norms differ in various situations, as individuals categorize themselves and others differently depending on the context (Aronson \& Inzlicht 2004), this paper contributes a particular angle to a growing body of research on student experiences of group-work. Previous studies have considered various aspects of diversity and group-work, such as interdisciplinarity and collaborative learning (Miles \& Rainbird 2015); work experience, gender and age (Gatfield 1999); gender and social class (Crossouard 2012); domestic and international students (Gatfield 1999), multiculturalism (Kimmel \& Volet 2010; Popov et al. 2012); race, age, and working with "slackers" (Payne \& Monk-Turner 2006); gender and performance (Takeda \& Homberg 2014) and gender, race, course performance and group leadership (Dingel \& Wei 2014). Due to the particularity of the South African national context and the historically white institution from which this research is situated (Department of Education 2008), for this study we focused on race and gender as two probable conscious or unconscious factors which may influence students' peer assessment of group contributions.

Recent studies continue to point to the relevance of considering race and gender when studying achievement motivation processes (Hope et al. 2013), and fairness in assessment (Willingham \& Cole 2013). Whilst work and gender has been well explored (for instance Gatfield 1999), this has not extended as much to the higher education context (Tolbert et al. 1999). When it comes to studies on race and group-work, the most influential work in this regard has come from concerns about wo/men of colour in historically white institutions in the United States (Rosser 1998; Chavous et al. 2002; Mendoza-Denton \& Page-Gould 2008). In most cases, these involved African American students who were in the minority when entering such universities, where it was concluded that members of historically marginalized groups are most likely to question their acceptance within such settings and feel mistrustful toward university representatives and authorities (Bowen \& Bok 1998; Stewart \& Dottolo 2005). Others have noted significant within- 
group variability in students' experience of such concerns (Aronson \& Inzlicht 2004; Walton \& Cohen 2007). Higher levels of race-based rejection sensitivity (RS-race) (Mendoza-Denton et al. 2002) in the US higher educationcontext has been directly linked to students feeling less of a sense of belonging than their ingroup members (Aronson \& Inzlicht 2004; Walton \& Cohen 2007). However, in cases of positive race-related experiences, it has been encouraging to note that feelings of belonging, among those students high in RS-race, were increased (Mendoza-Denton et al. 2002). Gender rejection sensitivity (RS-gender) has been explored extensively in the contexts of the academic disciplines of science, technology, engineering and mathematics (STEM) in higher education (Ahlqvist et al. 2013) to inform social justice-based interventions. However, these dynamics have not been explored to the same extent in contexts where the historically marginalised come to be the numerical majority, a transition currently occurring in previously white higher educationinstitutions in South Africa.

This study attempts to contribute such insights through an exploration of experiences and perspectives of undergraduate students interacting through group-work in the context of an historically white South African university. The findings are expected to better inform discourses on the peer assessment of group-members' contributions and student learning. At a more practical level, since the process involved 'insider researchers', the findings have informed evaluation for curriculum development processes towards enhancing students' learning experiences through this participatory assessment method.

After outlining the methodological approach adopted in this study, the initial insights into participants' positive and negative perceptions of the peer assessment of group-members' contributions which emerged from survey responses are outlined. Following this, we present a discussion of probable interpretations for the differences in these responses, inclusive of participants' reception of these interpretations, which leads to consideration of the significance for the curriculum of the case studied.

\section{Methodological approach}

This case study was conducted with the participation of undergraduate Environmental Science students at a South African university, where $3^{\text {rd }}$ year students undertake a year-long group based research project which contributes $32 \%$ of each individual's final grade. Peer assessment employed in the department ensured that students are rewarded for process (contribution) as well as product (assessment of submitted work). Incorporated in 2002, it was envisaged that the peer assessment of group-members' contributions would proactively prevent social loafing. In the hopes of less peer pressure and conflict within these groups, the identity of each report was protected. Aspects of inclusive group-work strategies were incorporated into the classroom (Rosser 1998), including projects that required cooperative effort. Common to national approaches aimed at addressing segregation in this post-apartheid contexts, groups composition was selectively organised to include diversity in terms of race, gender and the various subject majors. 
Aligned with institutional ethical requirements, students were informed and their voluntary, anonymous participation invited. Firstly, data were generated via a questionnaire at the end of each year, which included Likert-type statements to ranked responses (ranging from $1=$ Strongly Agree to 5 = Strongly Disagree) and open-ended questions. Likert-type statements gauged students' perceptions of issues relating to the peer assessment of group-members' contributions, including; whether they believed they should take part in assessing their group members' contribution, assessment criteria relevance, appropriateness, clarity and fairness, influence of student personal relationships on the process and effects of the peer assessment of group-members' contributions on student interaction, participation and learning. Open-ended questions focused on and allowed students to provide detailed explanations of their perceptions, experiences and reception of aspects of the peer assessment of group-members' contributions process and purposes. Our interpretations of this data, which are presented as 'Emerging insights' in this document, were then opened-up for validation and problematizing in a focus group interview, with those participants' responses included in our discussion of the findings. We are mindful of the fact that the student experience has significance for the ways in which they engage with their learning (Mann 2001), particularly within the communal activities of group-work, which incorporates affective concerns of inclusion and exclusion. Thus, the open-ended questions were designed to elicit insights on the impact of the peer assessment of group-members' contributions on their learning experiences and their dis/like of the peer assessment of group-members' contributions as practiced in the department. Illustrative excerpts of their responses are included in this paper.

In total, 41 of 52 students in the 2014 cohort and 27 out of 45 of the 2015 cohort participated in the survey, representing a combined response rate of about $70 \%$ in this initial phase. The scope was limited to race and gender as the typical dominant stereotype threats noted in students' wider narratives across the case study institution (Dennet 2015; Sonke Gender Justice 2016), though we are cognisant of the concern that traditional models may overlook the experiences of stereotype threats within multicultural groups (Shapiro 2011), including multilingualism (Andersson et al. 2013). More than half (60\%) of the respondents self-identified as 'white' (W), 12\% as 'black' (B) and 3\% as either 'coloured' or 'Indian'. The remaining percentage exercised their agency not to identify themselves racially (differentiated as NI for 'no identification'). We are mindful of the problematics associated with such distinctions, but have aligned these definitions with those categories common to national equity discourses of such demographics (Republic of South Africa 1998). The racial distinction 'white' is employed to define those of Caucasian descent, while 'black' as inclusive of those of black African descent, 'Indian' (a South Africa category known elsewhere as western Asian) and so-called 'coloured' (inclusive of those of 'mixed race' or KhoiSan descent). Whilst awkward, these distinctions were necessary as this study has attempted to explore in what ways the peer assessment of group-members' contributions may be influenced by such social structures.

With regards to gender, about $47 \%$ of the respondents identified as 'female' (F), $37 \%$ as 'male' (M), with the remaining choosing not to differentiate. To place these statistics within their context 
of demographic transformation, the numerical majority of undergraduate students at an institutional level in 2014 was composed of $66 \%$ B students of which $62 \%$ were F, with $34 \% \mathrm{~W}$ students of which 54\% were F (Rhodes University 2015). The total student headcount in 2015 was composed of $68 \%$ B students of which $71 \%$ were F, and $32 \% \mathrm{~W}$ students of which $29 \%$ were F (Rhodes University 2016). There are no conclusive indications for why the demographic compositions of the Environmental Science cohort differed from that of the larger institution.

With regards to data analyses of the survey responses, composite mean scores were used to analyse the different set of responses to the Likert-scale questions, using Microsoft Excel. Content analysis of the open-ended responses was used to identify, summarise and analyse the perceptions and experiences of respondents regarding the peer assessment of group-members' contributions, how it enhanced learning, why they dis/liked it and other common (emerging) themes. Specifically, for

the reasons behind dis/liking the peer assessment of group-members' contributions, descriptive statistics were used to quantify the number of times a reason was given across the entire sample and as disaggregated by race and gender. A Chi-squared test was used to analyse if responses were significantly different when disaggregated by gender and race.

Initial interpretations of this analysis, as represented in the 'Emerging insights' section, were shared electronically with all the participants (14) who had continued into postgraduate study, inviting further engagement. Of these, all voluntarily chose to participate in a report-and-respond session (Stronach \& MacLure 1997). Six were WF; 4 BF; 3 WM and 1 BM. Within this secondary phase, participants were first asked to respond in written form individually (indicated as 'individual responses'), and then participate in a focus group discussion with members differentiated according to racial category. This was followed by a plenary discussion (indicated as 'plenary') facilitated by one of the co-authors who was unknown to the students. The purpose of this interaction was to disseminate the initial findings and interpretation, and check these against the students' experiences, to enable more probing discussion, comment or challenge, in an inclusive and dialogical manner.

\section{Emerging insights}

\section{Positive perceptions of the peer assessment of group-members' contributions}

The mean score for all attitudinal variables combined was $(2.4 \pm 0.4)$, indicating that students were generally positive in principle about the practice of having peers assess group-members' contributions. About $90 \%$ of the students were in agreement with the practice of assessment of their peers' contributions to group tasks. Just over $60 \%$ of the respondents felt that the process supported learning. In their open-ended responses students identified the life skills critical in the working world which the peer assessment of group-members' contributions helped them to appreciate, including communication skills; better understandings of other group members; time management and multi-tasking; and the motivation to work and participate in group tasks. 
Peer assessment teaches you critical skills that one needs in a work place i.e. putting differences aside to complete the task. It also opens you up to new ideas (WF).

An assumption of the peer assessment of group-members' contributions is that it both discourages what is commonly called 'free riding' or 'social loafing' (Ashraf 2004; Oakley et al. 2004; Knight 2007), and acts as an external motivator (Yorke 2001) to improve participation and work ethic (Bostock 2000). In other studies, students have been found to be particularly appreciative of curricula and assessment methods which serve to moderate 'free-riding' (Maiden \& Perry 2011) in addition to those which incentivise group members' level of commitment (Swaray 2012). Students in this study noted that the peer assessment of group-members' contributions did provide some form of pressure for them to work harder at group-based tasks. Just over half the respondents felt it helped them to develop a sense of participation (52\%) and prevented free riding (54\%). A dominant example was their advance preparation of given tasks because they were cognisant that the level of individual preparedness affected their final marks.

If I keep in mind that my peer will influence my marks and I am under observation, I work hard towards the task given. I am not a lazy person when it comes to work, but I will probably work harder because I will be assessed by my peers (BF).

The majority (76\%) of $\mathrm{W}$ students who liked peer assessment mentioned that the peer assessment of group-members' contributions made group-based tasks fair as "students who do not work hard do not get a good mark", indicating the pressures of such a policy validated the majority of this group. Other studies have noted that a strong, positive racial group identification supports a positive relation between self-esteem and achievement (Hope et al. 2013), however what is disconcerting is that the inverse may equally apply. The most valued aspect of the peer assessment of group-members' contributions for that demographic was policing, as indicated in these illustrative excerpts.

I like that those that don't do their work will get a low mark. The fact that you get the marks you deserve and if your group did badly but you had to do all the work, you will be rewarded in such a way (WF).

Peer assessment motivates me to pull my weight and I often go beyond normal expectations to do well. In this way I learn more academically and become more integrated into my group (WF).

However, when it came to the impact of the peer assessment of group-members' contributions on their motivation, the average score for this attitudinal variable was $3.09 \pm 1.16$, indicating general indifference, uncertainty or ambivalence.

Students were asked if their peers' ratings enabled them to identify which of the areas they should focus on for improvement. The few respondents (22\%) who felt they benefitted from such diagnostic assessment pointed to how acting as assessors created an implicit comparison with their 
own contribution and helped them to self-assess their own performance. However, a substantial proportion of the students (75\%), with no significant differences in responses by gender and race, $p>0.05$ ) felt the peer assessment of group-members' contributions did not help them identify areas of weaknesses. As the convention of the report employed did not include written feedback, the numerical grade was experienced as insufficient for developmental purposes.

\section{Negative perceptions of the peer assessment of group-members' contributions}

Student responses to the more probing questions in the survey indicated variations and nuances in their reception, particularly when respondents were asked whether and why they dis/liked the peer assessment of group-members' contributions. More than two thirds of the respondents (66\%) said they disliked peer assessment, including considerably more B students (81\% or 17 out of 21$)$ than W students ( $63 \%$ or 26 out of 41 ) and a bigger proportion of $\mathrm{F}(88 \%$ or 28 out of 32) than M students $(52 \%$ or 13 out of 25$)$. Table 1 outlines the dominant reasons students provided for responding negatively to their experience.

Table 1: Survey respondents' reasons for a negative reception of the peer assessment of groupmembers' contributions

\begin{tabular}{|c|c|c|c|c|c|}
\hline \multirow[t]{3}{*}{ Reason } & \multirow{3}{*}{$\begin{array}{l}\text { Percentage }(\%) \\
\text { of respondents } \\
\text { overall }\end{array}$} & \multirow{2}{*}{\multicolumn{2}{|c|}{$\begin{array}{l}\text { Number of } \\
\text { students by race }\end{array}$}} & \multirow{2}{*}{$\begin{array}{l}\text { Number } \\
\text { students } \\
\text { gender }\end{array}$} & \multirow{2}{*}{$\begin{array}{l}\text { of } \\
\text { by }\end{array}$} \\
\hline & & & & & \\
\hline & & White & Black & Male & Female \\
\hline Concerns about partiality & 47 & 9 & 13 & 4 & 15 \\
\hline $\begin{array}{l}\text { The high numerical weighting } \\
\text { of the report }\end{array}$ & 31 & 10 & 1 & 6 & 7 \\
\hline $\begin{array}{l}\text { Miscomprehension of } \\
\text { assessment criteria }\end{array}$ & 12 & 6 & 2 & 2 & 4 \\
\hline Lack of usable feedback & 10 & 1 & 1 & 1 & 2 \\
\hline
\end{tabular}

More than half (59\%) of the respondents felt it was fair in principle to take their peers' ratings into account when allocating marks to each student for the year-long project. However, they simultaneously expressed concerns that the process in practice was flawed. The remaining indicated they disagreed $(13 \%)$ or were unsure $(28 \%)$, with ambivalence being a consistent characteristic of students' responses to this issue.

Peer assessments can be useful for learning but are rarely impartial and are usually motivated by factors other than the task at hand (NI). 
Confirming studies on students' distrust of their peers' abilities to fairly assess them (Lladó et al. 2014), about $47 \%$ of the respondents pointed to a lack of impartiality in the assessment process. As none of the students in this study were privy to the marks allocated by their peers, this perception was not based on their knowledge of the actual numerical values assigned to them. Regardless, they were concerned that assessments may not be based on the work produced or contribution made, but that judgments were influenced by emotions and the nature of personal relationships. In the ranked responses, $65 \%$ at first responded that they were personally able to assess their peers fairly. The remaining $25 \%$ were indifferent or unsure, and $10 \%$ indicated that they sensed their judgements were unfair. This was triangulated with a later statement that "my general relationship with group members influences the marks I allocate to them" (mean score was $3.6 \pm 0.7$ ), where about $30 \%$ of all the respondents admitted that their relationship with group members influenced the marks they allocated to peers, while $21 \%$ provided a noncommittal or ambivalent response. This suggests that more than half of the respondents acknowledged that factors other than the quality of members' contributions may have influenced their own decisionmaking when allocating marks. It is therefore not surprising that some students felt that some group members "marked others down" because of "personal reasons" (BM), "issues" (WF), "based upon friendship rather than work" (NI).

Idealised constructions of group-work are that they promote team work, cooperative working methods and understanding of one another; create opportunities to learn from others' experiences, new ways of doing things and ways of dealing with conflicts and disagreements; and in so doing increase students' preparedness for culturally diverse work environments (Levin 2005). In this study such notions were undermined by the dominant feeling that group members' ratings were not impartial. In the open-ended responses, students highlighted that when conflicts arose in the group, they believed ratings were affected and group-work became unpleasant.

It demotivates me because I start to dislike my group because I don't trust them at all (WF).

When analysed by gender and race, generally more F students (78\%) than M students (22\%) and more B students (62\%) than W students (38\%) felt these assessments were not impartial. Most BFs highlighted this as a concern about peers' assessment of their own work.

If a person in a group does not like you, they will mark you down because of personal reasons $(\mathrm{BF})$.

I dislike the fact that it allows individuals a platform for personal vendettas (BF).

Some people in the group are sometimes favoured and regardless of their participation they get good marks (BF).

An interpretation of this prevalence, consistent with notions of group-value theory, was that participants' concerns around fairness, respect, and acceptance might have been influenced by rejection-sensitivity and related self-esteem (Mendoza-Denton et al. 2010). 
More than $70 \%$ of the respondents felt that the assessment criteria were well explained and over $80 \%$ felt these were clear and easy to use while assessing their peers' contributions. Confirming studies which have linked student satisfaction with the shared understanding of criteria used (Brooks \& Ammons 2013), a minority of students (12\% which was too small for statistical comparison in terms of race and gender) identified a reason for their negativity was what they experienced as being a lack of uniform understanding of the marking criteria, which created doubt as to the reliability and validity of the mark allocation. Arguably, a more transparent process might have mitigated against judgments consciously or unconsciously being influenced by bias, and in turn better inform perceptions of the process by those vulnerable to rejection-sensitivity.

\section{Student receptions of these interpretations}

The survey generated data on students' perceptions of the peer assessment of group-members' contributions of a year-long Environmental Science research project at an historically white South African university. While survey respondents exhibited positive attitudes towards peer assessment in principle, we further probed the nuances and reasons for their often ambiguous responses using an approach where we reported on the analysis and interpretations outlined in the previous sections. Students' individual and focus group interview responses to these interpretations confirmed that people of different backgrounds have different experiences of the same situation (which Steele (1997) terms a 'stereotype threat'). In this section, which is inclusive of participants' voices, we discuss how our findings concur with studies that suggest that students' background affects their perceptions of the challenges of diverse group-work (Popov et al. 2012),.

Emerging from the survey responses were distinct differences in the gender and racial composition of students who disliked the peer assessment of group-members' contributions. Those who liked it mainly highlighted social control, where the assessment of a peer's contribution to group-based tasks exerts a form of peer pressure for students to work harder. It is argued, from a behaviourist perspective, that the possible humiliation of the poor quality of a student's contribution being assessed by peers, and the likely criticism from peers if a student were to fail to complete a given component of the group-based task, is harnessed through the process of the peer assessment of group-members' contributions (Gibbs \& Simpson 2004). Consistent with findings of an earlier study in this context (Thondhlana \& Belluigi, 2014) as with many other studies across the globe (Ashraf 2004; Oakley et al. 2004; Knight 2007), social loafing in group-based tasks was one of the major issues highlighted by students.

However, our analysis indicated the complexities of such social pressure when combined with the gaze and power of assessment. A striking finding of the study was that the majority of the students in favour of the peer assessment of group-members' contributions for policing purposes were white, consistent with the historical demographic of the 'ideal' student at this institution, which was originally established by British colonialists. This majority preference may be indicative of either self-confident evaluations of such student contributions and work ethic, and/or inversely prejudicial stereotyping of 'other' group members as having the potential to free ride, on the basis

Preprint 
of societal constructs, including perceived deficit, possible dependence or 'laziness' (Durrheim et al. 2011; Grant 2014).

When presented these possible interpretations at the report-and-respond session, students' reception was sharply divided on racial lines. All B respondents agreed with this interpretation, as these excerpts illustrate.

Just a simple task of assigning marks to other people puts one in a position of power and if, in this context, it puts a white man in a position of power and, in doing so, it also enhances and validates his own self-image, as well as fuelled that superiority complex that has informed so many of his decisions that happened in the past as well as the social dynamics that it is today (B group spokesperson, plenary).

To a certain extent I think it does validate the typical "white male" self-image of being superior, which isn't to say that they do more work or work harder than everyone else, but probably an issue of upbringing (BF, individual response).

In their individual written responses, 2 of the $3 \mathrm{WM}$ respondents sharply disagreed with this interpretation "as it suggests that the peer assessment of group-members' contributions is about anything other than the merit of their work", offering in contrast a construction of assessment as a neutral activity. Emerging from the W groups' responses was an explicit distancing from any identification with inherited negative racial associations, including that of the "discriminators" (WM) or "racists" (WF) of apartheid and the idealised knowers of western colonial ontologies (Lebakeng et al. 2006).

I definitely don't want to validate my self-image and don't feel 'white pride' (WF, plenary).

Two of the $\mathrm{M}$ respondents recognised, in their individual written responses, that validation was an aspect of the process of the peer assessment of group-members" contributions ("the reason for the policing" (WM)). However, the B student indicated awareness of how this may be influenced by the socio-political context "given South Africa's history of stereotypical others being policed in one way or another by those who are deemed ideal by the social constructs of the time" (BM).

We don't feel seen as black people. And so, you'd give me lower marks. Not because I didn't perform, not that I didn't represent myself well, but because you guys just didn't notice me (BF, plenary).

The low satisfaction expressed by B students and some WF students may have been indicative of RS-race and RS-gender where preconceptions, of being possible social loafers or lacking in proficiency to provide quality contributions, were imagined as projected onto them. This interpretation was confirmed by all B respondents.

Just because the historical context and the current context of today, I would obviously expect to encounter some sort of racism in my class. That's not to say I have but this is, 
like hypothetically speaking, it would make sense for that person to have that rejection sensitivity towards that. Just because it's something they have been exposed to for generations (B group spokesperson, plenary).

In the current South African higher education context, certain ethnic and economic groups have historically been disadvantaged by their exclusion from quality primary and secondary schooling, in addition to many being first generation university students. Their level of preparedness has long been a subject of national and institutional discussion. Blanket labelling of all black students by such deficit discourses, which are themselves problematic (O'Shea et al. 2016), are not uncommon (nor specific to South Africa, see McKay \& Devlin 2016). Such discourses emerged as playing out in the perceptions of these students to the peer assessment of group-members' contributions, and unwittingly supporting both bias and RS-race. In the plenary, the B group articulated their perception that W students perceived B students "can't manage up to their abilities or capabilities, they need to be policed and supervised at all times in some way or other". Such responses, emanating from one's uncertainty about how one's academic knowledge is perceived, has been found to undermine intellectual performance and interfere with academic self-knowledge in other contexts (Aronson and Inzlicht 2004). All B interview respondents at the plenary confirmed the interpretation of rejection-sensitivity, citing anecdotes of being made to feel invisible in contexts within and outside the university, but also acknowledging that such projections may be affected by their own self-image and by mental colonisation,

... based on the grounds of historical prejudice and racism. So bearing that in mind, that person will already have preconceived notions on how other people view them (B group, spokesperson).

Whilst most W students found it difficult initially to comprehend the concept of rejectionsensitivity, which in itself may be an indication of social privilege, many F students of that group came to express empathy ("super outcasted") with such experiences during the plenary process as the concept and examples were shared.

Noticeably, what the survey respondents perceived to be the key challenges differed between $\mathrm{W}$ and B students. Though concerns were articulated across the racial divide, most B students perceived that the peer assessment of group-members' contributions was prone to influences of personal relationships and bias. Subsequently, these students felt that PAGC did not fairly reflect the amount of work and effort they put into completing group-based tasks, resulting in grades they surmised were an inadequate measure and skewed representation of their individual contributions. A consequence of peer ratings not being made known to group members was that students were not privy to the distribution of their peer review marks in terms of their (a) attendance, punctuality and reliability, (b) academic contribution, (c) quality of work produced, and (d) share of the workload. Thus, perceptions of partiality arose from either admissions or perceptions of bias, as at that time there were no means available to students to compare group member assessments, exacerbating RS-race and RS-gender belonging uncertainty. 
All WF participants at the plenary confirmed that bias fed into their assessments of their peers. Whilst resisting suggestions that racial relations fed consciously into their own bias, their responses did suggest this played a latent influence.

I believe this is independent of race or gender, but links to relationships, and sadly to say at university, most people are friends within their race and gender group before others (WF, individual response).

The tendency to favour in-group over out-group members in the allocation of resources or personal judgment has been found to be a pervasive tendency in humans (Giannakakis \& Fritsche 2011). This underpinned a presumption of bias inherent to the B students which $\mathrm{W}$ group articulated the plenary discussion, that "possibly black people dislike peer review because of their history of struggle and being united" and that "the black race to work together to succeed and therefore they may feel that the policing element of the peer assessment of group-members' contributions is against cultural/societal norms as why throw a mate under the bus". In response, the B group offered their perception that counter-transference was more common in their lived experience.

BM: The pervasive mentality that exists especially among black youth today, the world over, is the 'crabs in a bucket' mentality. Where you'll try and pull another black person down. Obviously this extends way beyond the confines of the classroom...much broader life issue... even sometimes in the case of peer assessments, just marking them down even just slightly, just to make sure that they get one up on them -

BF: - that they are the 'better' black person -

BM: Exactly. [laughs]

Due to differences in preferences, attitudes and perceptions of 'others', signifiers of difference have been identified as possible constraints for productive learning in group-work (Nguyen et al. 2008). What is most disconcerting is that these perceptions, whether real or perceived, may import and perpetuate societal stereotypes against particular groups of people, which can constrain students' learning experiences and, in turn, the social justice mandate of higher education. The partiality concerns raised by respondents, highlights the importance of teaching student-assessors how to make fair judgements about their own performance and that of others. Criterion-referenced assessment as opposed to norm-referenced assessment can be helpful in this regard, helping students negotiate expectations and standards, and establishing group norms explicitly towards fairness and transparency. The valid concerns raised by the participants of this study, albeit a minority, echoes research that suggests that peer assessment can focus learning if students understand the reason behind their mark and the reasons for not scoring higher (Gibbs \& Simpson 2004).

This research has resulted in a curricular shift from the emphasis on technical and policing functions of guarding against and penalising social-loafing, to advancing understanding through 
the provision of explanations against a given set of criteria with specific suggestions for improvement. It is hoped that such additional peer feedback would improve the transparency, and thereby credibility, of the assessment process by enabling deeper consideration and contestation. This also aligns with the curriculum designer's developmental stance - that the formative benefits of the peer assessment of group-members' contributions, as a way of facilitating and enhancing learning, are more important than assessment for measurement or as a coercive policing mechanism. In addition, discussions about the values, purposes, criteria and expectations of the peer assessment of group-members' contributions with students are being introduced early on in their group interactions, with an emphasis on those processes being understood as a means of supporting and deepening learning. Such open-ended discussions are intended to orientate students with the assessment criteria, and help conscientise students to possible personal factors and prejudices from societal stereotyping that may infuse their assessment, and to possible RS projections of the partiality of their peers' ratings which may undermine the effectiveness of the peer assessment of group-members' contributions.

Of concern is the argument that patterns of social oppression that exist in the societal context may be repeated and replicated in group-work, unless active steps are taken to counteract these tendencies and replace them with a culture of empowerment (Brown \& Mistry 1994). Designing assessment capable of augmenting equity requires a thorough and alternate consideration of the way learning is to be assessed, and the effect of the assessment process on different individuals and groups (Killen 2005). It is a challenge to design assessment with enough flexibility to cater to the requirements of different students whilst continuing to maintain integrity (Hayes \& Adams 2013). Towards this, the possibilities of perspective-taking (Galinsky \& Ku 2004) and values affirmation (Miyake et al. 2010) are currently being considered for future course iterations. In addition, there will be particular attention paid to group composition and role rotation (leadership et cetera), ensuring students fill a variety of roles throughout the year to challenge, through their experiences and performance, societal stereotypes (Rosser 1998). Despite their misgivings, participants of the focus group interview confirmed that group-work and inter-racial familiarity does have the potential to challenge stereotypes.

I've found that white people have a pre-determined/ pre-conceived attitude regarding black people. [It] changes when I speak and say what school I went to or when my essay marks are higher. Then they trust me more (BF, individual response).

For me, that kind of racial divide and perceptions and all of that stuff fell away when you got to know the person. I think these kind of things do matter and the historical context does matter and you do come in with these perceptions, but over the long term when you get to know that person, I think that for me, that disappears (WF, plenary). 


\section{Conclusion}

The potential of peer assessment to promote learning often forms the rationale for its adoption in university courses. However, based on these emergent findings, we would argue that the influences of societal differences, whether actual or imagined, warrant a better understanding since they may have serious implications for students' active participation in group-work. Traces of the history of privilege and discrimination in South Africa emerged in how participating students identified themselves and were identified, in addition to latent prejudice and rejection-sensitivities evident in their reception of how contributions to group-work were assessed. The findings of this research study strongly indicate that the conditions for students' successful engagement with the peer assessment of group-members' contributions should not be presumed, as assessment is contextspecific with socio-cultural influences. They also suggest that diversity is a liability to quality when society's negative stereotypes and associations, such as those about the relation between race or gender and academic competence, inhibit such interactions (Shepard 2008).

In the past two decades South African higher education has been characterised by concerns with numerical access - enabling the representation of different demographics - and epistemological access (Morrow 2007) - access to disciplinary ways of knowing to enable success. This paper goes a step further to contribute to studies on the complexities of relational or interactional diversity (Fine et al. 1997; Gurin et al. 2002). In a tradition of research which acknowledges the impact of societal constructions and asymmetries in assessment, this study contributes to those which explore the subtleties of identity-group-based diversity and its relation to experience and performance (Ely et al. 2012). At a point in the history of South African higher education, where students from different groups are interacting in complex ways, this study hopes to inform the conditions which bring students together, moving towards a time when all group members feel hospitality and solidarity.

\section{References}

Ahlqvist, S., B. London, \& L. Rosenthal. 2013. "Unstable Identity Compatibility How Gender Rejection Sensitivity Undermines the Success of Women in Science, Technology, Engineering, and Mathematics Fields." Psychological Science 24: 1644-1652.

Andersson, I., A. M. Kagwesage, \& J. Rusanganwa. 2013. "Negotiating Meaning in Multilingual Group Work: A Case Study of Higher Education in Rwanda." International Journal of Bilingual Education and Bilingualism 16: 436-450.

Aronson, J., \& M. Inzlicht. 2004. "The Ups and Downs of Attributional Ambiguity Stereotype Vulnerability and the Academic Self-Knowledge of African American College Students." Psychological Science 15:829-836.

Ashraf, M. 2004. "A Critical Look at the Use of Group Projects as a Pedagogical Tool”. Journal of Education for Business 79: 213-216. 
Bloxham, S., \& P. Boyd. 2007. Developing Effective Assessment in Higher Education. Maidenhead: Open University Press.

Bostock, S. 2000. "Student peer assessment". Higher Education Academy. Available at http://www.heacademy.ac.uk/assets/York/documents/resources/resourcedatabase/id422_student_ peer_assessment.pdf

Boud, D. 2000. "Sustainable Assessment: Rethinking Assessment for the Learning Society." Studies in Continuing Education 22: 151-167.

Boud, D., \& N. Falchikov. 2006. "Aligning Assessment with Long-term Learning." Assessment \& Evaluation in Higher Education 31: 399-413.

Bowen, W. G. \& Bok, D. 1998. The shape of the river. Princeton: Princeton University Press.

Brooks, C. M., \& J. L Ammons. 2003. "Free Riding in Group Projects and the Effects of Timing, Frequency, and Specificity of Criteria in Peer Assessments." Journal of Education for Business 78: 268-272.

Brown, A., \& T. Mistry. 1994. "Group Work with 'Mixed Membership' Groups.” Social Work with Groups 17: 5-21.

Chavous, T., Rivas, D., Green, L., \& Helaire, L. 2002. "Role of Student Background, Perceptions of Ethnic Fit, and Racial Identification in the Academic Adjustment of African American Students at a Predominantly White University". Journal of Black Psychology 28(3): 234-260.

Chemers, M. M., L. Hu, \& B. F. Garcia. 2001. "Academic Self-efficacy and First-year College Student Performance and Adjustment." Journal of Educational Psychology 93: 55-64.

Crandall, C. S., A. J. Bahns, R. Warner, \& M. Schaller. 2011. "Stereotypes as Justifications of Prejudice." Personality and Social Psychology Bulletin 37: 1488-1498.

Cross, M. \& C. Carpentier. 2009. "New Students in South African Higher Education: Institutional Culture, Student Performance and the Challenge of Democratisation." Perspectives in Education 27: 6-18.

Crossouard, B. 2012. "Absent Presences: The Recognition of Social Class and Gender Dimensions within Peer Assessment Interactions.” British Educational Research Journal, 38: 731-748.

Department of Education. 2008. Report of the Ministerial Committee on Transformation and Cohesion and the Elimination of Discrimination in Public Higher Education Institutions. Pretoria: South African Department of Education. 
Dennet, B. 2015. "Rhodes University: A demand for transformation". Mail \& Guardian online. Retrieved 19 May 2016 at http://mg.co.za/article/2015-09-09-rhodes-university-a-demand-for$\underline{\text { transformation }}$

De Wever, B., H. Van Keer, T. Schellens, \& M. Valcke. 2011. “Assessing Collaboration in a Wiki: The Reliability of University Students' Peer Assessment." The Internet and Higher Education 14: 201-206.

Dingel, M. \& W. Wei. 2014. "Influences on Peer Evaluation in a Group Project: An Exploration of Leadership, Demographics and Course Performance." Assessment \& Evaluation in Higher Education 39: 729-742.

Durrheim, K., X. Mtose, and L. Brown, 2011. Race Trouble: Race, Identity and Inequality in PostApartheid South Africa. Lexington Books.

Ely, R. J., I., Padavic \&, D. A. Thomas. 2012. "Racial Diversity, Racial Asymmetries, and Team Learning Environment: Effects on Performance.” Organization Studies 33: 341-362.

Fine, M., Weis, L. \& Powell, L.C. 1997. "Communities of difference: a critical look at desegregated spaces created for and by youth". Harvard Educational Review 67: 247-284.

Freeman, M., \& McKenzie, J. 2002. "SPARK, a confidential web-based template for self and peer assessment of student teamwork: benefits of evaluating across different subjects". British Journal of Educational Technology 33:551-569.

Galinsky, A. D., \& G. Ku. 2004. "The Effects of Perspective-Taking on Prejudice: The Moderating Role of Self-Evaluation.” Personality and Social Psychology Bulletin 30: 594-604.

Gatfield, T. 1999. "Examining Student Satisfaction with Group Projects and Peer Assessment." Assessment \& Evaluation in Higher Education 24: 365-377.

Gibbs, G. \& C. Simpson. 2004. "Conditions under which Assessment Supports Students' Learning.” Learning and Teaching in Higher Education 1: 3-31.

Giannakakis, A. E., \& I. Fritsche. 2011. "Social Identities, Group Norms, and Threat: On the Malleability of Ingroup Bias.” Personality and Social Psychology Bulletin 37: 82-93.

Gielen, S., F. Dochy, P. Onghena, K. Struyven, \& S. Smeets. 2011. "Goals of peer assessment and their associated quality concepts.” Studies in Higher Education 36: 719-735.

Grant, T. 2014. "Poll: Most Whites say Blacks are Lazier or Less Intelligent than Whites". Retrieved February 5, 2016, from http://tobingrant.religionnews.com/2014/12/08/poll-whites-sayblacks-lazier-less-intelligent-whites-3-graphs/ 
Gurin, P., Dey, E.L., Hurtado, S., \& Gurin, G. 2002. "Diversity and higher education: Theory and impact on educational outcomes". Harvard Educational Review 72: 330-366.

Hattie, J. A. 1987. "Identifying the salient facets of a model of student learning: a synthesis of meta-analyses." International Journal of Educational Research 11. 187-212.

Hayes, C., \& N. Adams. 2013. "Assessment in an Era of Increased Social Inclusion in Higher Education." International Journal of Arts \& Sciences 6: 31-41.

Hogg, M. A. \& Turner, J. C. 1987. "Intergroup behaviour, self-stereotyping and the salience of social categories. British Journal of Social Psychology 26 (4): 325-340.

Hope, E. C., T. M. Chavous,R. J. Jagers, \& R. M. Sellers. 2013. “Connecting Self-Esteem and Achievement Diversity in Academic Identification and Dis-identification Patterns among Black College Students.” American Educational Research Journal 50: 1122-1151.

Johnston, L., \& L. Miles. 2004. “Assessing Contributions to Group Assignments.” Assessment \& Evaluation in Higher Education 29: 751-768.

Jones, I., \& L. Alcock. 2014. "Peer Assessment without Assessment Criteria." Studies in Higher Education 39: 1774-1787.

Killen, R. 2005. "Programming and Assessment for Quality Teaching and Learning”. Southbank: Thomson/Social Science Press.

Kimmel, K., \& S. Volet, 2010. "Significance of Context in University Students' (Meta)cognitions related to Group Work: A Multi-layered, Multi-dimensional and Cultural Approach.” Learning and Instruction 20: 449-464.

Knight, D. D., 2007. "Pairing vs. Small groups: A Model for Analytical Collaboration." The Teaching Professor 21 (2): 5.

Knight, P. 2001. "A Briefing on Key Concepts - Formative and Summative, Criterion \& Normreferenced Assessment." Assessment Series No. 7. York: Learning and Teaching Support Network, Generic Centre.

Lladó, A. P., L. F. Soley, R. M. F. Sansbelló,G. A. Pujolras, , J. P.Planella, , N.Roura-Pascual, \& L. M. Moreno.. 2014. "Student Perceptions of Peer Assessment: An Interdisciplinary Study." Assessment \& Evaluation in Higher Education 39: 592-610.

Lebakeng, J.T., Phalane, M.M. \& Dalindjebo, N. 2006. Epistemicide, Institutional Cultures and the Imperative for the Africanisation of Universities in South Africa. Alternation 13 (1):70-87.

Lejk, M., M. Wyvill, \& S. Farrow. 1996. "A Survey of Methods of Deriving Individual Grades from Group Assessments.” Assessment \& Evaluation in Higher Education 21: 267-280. 
Levin, P. 2005. Successful teamwork. New York: McGraw-Hill Education.

Maiden, B., \& B. Perry. 2011. "Dealing with Free-riders in Assessed Group Work: Results from a Study at a UK University." Assessment \& Evaluation in Higher Education 36: 451-464.

Mann, S. 2001. "Alternative Perspectives on the Student Experience: Alienation and Engagement." Studies in Higher Education 26: 7-18.

McKay, J., \& Devlin, M. 2016. "Low income doesn't mean stupid and destined for failure: challenging the deficit discourse around students from low SES backgrounds in higher education". International Journal of Inclusive Education 20 (4): 347-363.

Mendoza-Denton, R., G. Downey, V. J. Purdie, A. Davis, \& J. Pietrzak. 2002. "Sensitivity to Status-based Rejection: Implications for African American Students' College Experience." Journal of Personality and Social Psychology 83: 896-918.

Mendoza-Denton, R., M. Goldman-Flythe, J., Pietrzak, G. Downey, \& M. J. Aceves. 2010. "Group-Value Ambiguity Understanding the Effects of Academic Feedback on Minority Students' Self-Esteem." Social Psychological and Personality Science 1: 127-135.

Mendoza-Denton, R. \& E. Page-Gould. 2008. "Can Cross-Group Friendships Influence Minority Students' Well-Being at Historically White Universities?” Psychological Science 19 (9): 933-39

Miles, M., \& S. Rainbird. 2015. "Evaluating Interdisciplinary Collaborative Learning and Assessment in the Creative Arts and Humanities." Arts and Humanities in Higher Education 14: 409-425.

Miyake, A., L. E. Kost-Smith, N. D. Finkelstein, S. J. Pollock, G. L.Cohen, \& T. A. Ito. 2010. "Reducing the Gender Achievement Gap in College Science: A Classroom Study of Values Affirmation." Science 330: 1234-1237.

Morrow, W. E. 2007. Learning to Teach in South Africa. Cape Town: HSRC Press.

Nguyen, P. M., C. Terlouw \& A. Pilot. 2008. "Culturally Appropriate Pedagogy: The Case of Group Learning in a Confucian Heritage Culture Context." Intercultural Education 17: 1-20.

Oakley, B., R. M. Felder, R., B. \& I. Eljaj. 2004. “Turning Student Groups into Effective Teams.” Journal of Student Centred Learning 2: 9-33.

Orr, S. 2010. "Collaborating or Fighting for the Marks? Students' Experiences of Group Work Assessment in the Creative Arts." Assessment \& Evaluation in Higher Education 35: 301-313. 
O'Shea, S., Lysaght, P., Roberts, J. \& Harwood, V. 2016. "Shifting the Blame in Higher Education - Social Inclusion and Deficit Discourses." Higher Education Research \& Development 35 (2): $322-36$.

Payne, B. K., \& E. Monk-Turner. 2006. "Students' Perceptions of Group Projects: The Role of Race, Age, and Slacking." College Student Journal 40(1), 132.

Popov, V., D. Brinkman, H. J. A. Biemans, M. Mulder, A. Kuznetsov, \& O. Noroozi, 2012. "Multicultural Student Group Work in Higher Education: An Explorative Case Study on Challenges as Perceived by Students." International Journal of Intercultural Relations 36: 302317.

Republic of South Africa. 1998. "Employment Equity Act No 55". Government Gazette 400 No 19370. Cape Town.

Rhodes University. 2015. Rhodes University Digest of Statistics 19. Available at http://www.ru.ac.za/media/rhodesuniversity/content/dmu/documents/digest15.pdf

Rhodes University. 2016. Total student headcount for 2016 as per HEMIS submission (as yet unaudited at time of paper submission).

Rosser, S. 1998. "Group Work in Science, Engineering, and Mathematics: Consequences of Ignoring Gender and Race." College Teaching 46: 82-88.

Shapiro, J. R. 2011. "Different Groups, Different Threats: A Multi-Threat Approach to the Experience of Stereotype Threats." Personality and Social Psychology Bulletin 37: 464-480.

Shepard, L. A. 2008. "The Role of Assessment in a Learning Culture." Educational Researcher 29: 4-14.

Steele, C. M. 1997 "A threat in the air: How stereotypes shape intellectual identity and performance”. American Psychologist 52: 613-629.

Sonke Gender Justice. 2016. "News release: Call for policy reform at Rhodes University following release of list of alleged rapists". Sonke Gender Justice. Retrieved 19 May 2016 from http://www.genderjustice.org.za/news-item/call-policy-reform-rhodes-university-followingrelease-list-alleged-rapists/

Stewart, A. J., \& Dottolo, A.L. 2005. "Socialization to the academy: Coping with competing social identities". In G. Downey, J.S. Eccles, \& C.M. Chatman (Eds.), Navigating the future: Social identity, coping and life tasks (pp. 167-187). New York: Russell Sage.

Stronach, I., \& MacLure, M. 1997. Educational Research Undone: The Postmodern Embrace. Philadelphia, Pa: Open University Press. 
Swaray, R. 2012. "An Evaluation of a Group Project Designed to Reduce Free-riding and Promote Active Learning." Assessment \& Evaluation in Higher Education 37: 285-292.

Takeda, S., \& F. Homberg. 2014. "The Effects of Gender on Group Work Process and Achievement: An Analysis through Self- and Peer-assessment." British Educational Research Journal 40: 373-396.

Thondhlana, G \& D. Z. Belluigi. 2014. "Group Work as 'Terrains of Learning' for Students in South African Higher Education." Perspectives in Education 32: 40-55.

Tolbert, P. A., M. E. Graham, \& A. O. Andrews. 1999. "Group Gender Composition and Work Group Relations: Theories, Evidence and Issues. In G. Powell (Ed.), Handbook of gender and work. Thousand Oaks, CA: SAGE.

Turner, J. C., M. A. Hogg, P. J. Oakes, S. D. Reicher, \& Wetherell, M. S. 1987. Rediscovering the social group: A self-categorization theory. Oxford and New York: Blackwell.

Walton, G. M., \& G. L Cohen. 2007. "A question of Belonging: Race, Social fit, and Achievement." Journal of Personality and Social Psychology 92: 82-96.

Willingham, W. W., \& N. S. Cole. 2013. Gender and Fair Assessment. Routledge.

Yorke, M. 2001. "Formative assessment and its relevance to retention." Higher Education Research and Development 20: 115-126. 